\title{
A wheat-fallow rotation in northeastern Spain: water balance-yield considerations
}

\author{
KJ McAneney 1, JL Arrúe 2 \\ ${ }^{1}$ Kerikeri Horticultural Research Station, PO Box 23, Kerikeri (Bay of Islands), New Zealand; \\ 2 Consejo Superior de Investigaciones Científicas, Estación Experimental de Aula Dei, Apartado 202, E50080 Zaragoza, Spain
}

(Received 17 June 1992; accepted 17 March 1993)

\begin{abstract}
Summary - A 35-yr time series of dryland wheat yields and corresponding monthly rainfall data from the Los Monegros/La Ribera del Ebro-Zaragoza area in Central Aragon have been examined with a view to determining the efficacy of the wheat-fallow rotation. Grain yields are low (average of $1050 \mathrm{~kg} / \mathrm{ha}$ ) and highly dependent on seasonal (October-May) rainfall. In some years no harvestable yield is possible. The contribution of stored water during the fallow period appears minor either because of a low soil water-holding capacity, poor weed control, or because of the nature of the rainfall distribution. The latter is characterised by the absence of any well-defined rainy season and in any month there exists a strong probability of having either no or an extremely low amount of rain $(<10 \mathrm{~mm})$. The Tanner and Sinclair (1983) result suggesting that transpiration efficiency is a stable characteristic for a cropping system is used to calculate transpiration from grain yields. Evaporative losses are then calculated by difference with the seasonal rainfall on the assumption that drainage and surface runoff were negligible. On average, $70 \%$ of the average seasonal rainfall is estimated to be lost either as evaporation or transpiration by weeds. The water use efficiency of grain production approached the average potential $\left(16.7 \mathrm{~kg}^{\bullet} \mathrm{ha}^{-1}\right.$ per $\mathrm{mm}$ water transpired) in only 3 out of $35 \mathrm{yr}$. In other years, evaporative losses accounted for a greater proportion of evapotranspiration, reflecting reductions in growth due to factors other than water such as poor plant nutrition, pests and diseases, etc.
\end{abstract}

dryland wheat / water budget / semi-arid region / fallow period / dry matter production / grain yield / water-use efficiency

Résumé - Un système de culture blé-jachère au nord-est de l'Espagne : efficience de jachère et relation bilan hydrique-rendement. Dans le but de déterminer l'efficacité d'une rotation blé-jachère, on analyse une série de 35 ans de données de production de blé et les pluviométries mensuelles correspondantes sur les zones de Los Monegros et de La Ribera del Ebro-Zaragoza, dans le centre de l'Aragon (Espagne). Les rendements en grains sont faibles (1050 kg/ha en moyenne) et dépendent fortement des précipitations saisonnières (octobre-mai). La contribution de l'eau stockée pendant la période de jachère apparaît peu importante, en raison soit de la faible réserve utile du sol, soit du contrôle insuffisant des mauvaises herbes, soit de la distribution des pluies. Celle-ci se caractérise par l'absence d'une saison pluvieuse bien définie et par une forte probabilité de précipitations mensuelles non efficaces $(<10$ $\mathrm{mm}$ ). La conclusion de Tanner et Sinclair (1983), selon laquelle l'efficacité de la transpiration est une caractéristique stable d'un système de culture donnée, est utilisée ici pour évaluer la transpiration à partir des rendements en grain. Les pertes par évaporation sont ensuite estimées par différence avec la précipitation saisonnière, sous l'hypothèse d'un drainage et d'un ruissellement superficiel négligeables. En moyenne, $70 \%$ des précipitations sont considérées comme perdues par évaporation ou transpiration par les mauvaises herbes. L'efficience de l'utilisation de l'eau pour la production de grains ne s'est approchée du potentiel moyen $\left(16,7 \mathrm{~kg}_{\text {. ha }}{ }^{-1}\right.$ par $\mathrm{mm}$ de l'eau transpirée) que dans 3 années sur les 35 étudiées. Pour les autres années, les pertes par évaporation supérieures indiquent sans doute que les réductions de croissance sont liées à d'autres facteurs que l'eau, comme le manque d'engrais, les insectes, les maladies des plantes, etc.

blé non irrigué / bilan hydrique / semi-aride / jachère / matière sèche / rendement en grain / efficience de l'utilisation de l'eau 


\section{INTRODUCTION}

Central Aragon in north-eastern Spain is one of the driest regions of the Iberian peninsula. Here 2 of the most important areas for cereal production, La Ribera del Ebro and Los Monegros (fig 1), comprise some 250000 ha of semi-arid drylands with an average annual rainfall of $<400$ $\mathrm{mm}$. This low rainfall regime imposes significant constraints on agricultural production (Alberto and Machín, 1978) and is due to the mountain chains which border the Ebro River Valley, which present formidable barriers for rain-carrying storms from almost any direction. The traditional farming system is that of a cereal-fallow rotation. As in many other places, the use of the fallow period has been questioned, and in this paper we examine historical wheat yields and rainfall data in order to obtain some indications of its effectiveness in this region. A comprehensive study of fallow systems should consider, in addition to the water budget, effects on soil fertility, soil-borne diseases, weed control efficiency, flexibility of farming operations, livestock integration and costs of production. Only water balance issues will be addressed in this paper.

The inclusion of a weed-free fallow or 'resting' period is widely used in semi-arid regions to recharge soil water storage and increase the water available for the next crop. In an oft-quoted 30-yr comparison on the Great Plains, Smika (1970) found average fallow-wheat yields to be $>3$ times greater than those from continuouslycropped plots. Moreover, the fallow-wheat system proved more stable with no crop failures, whereas with a continuous wheat system, no harvestable yield was obtained in $>30 \%$ of the

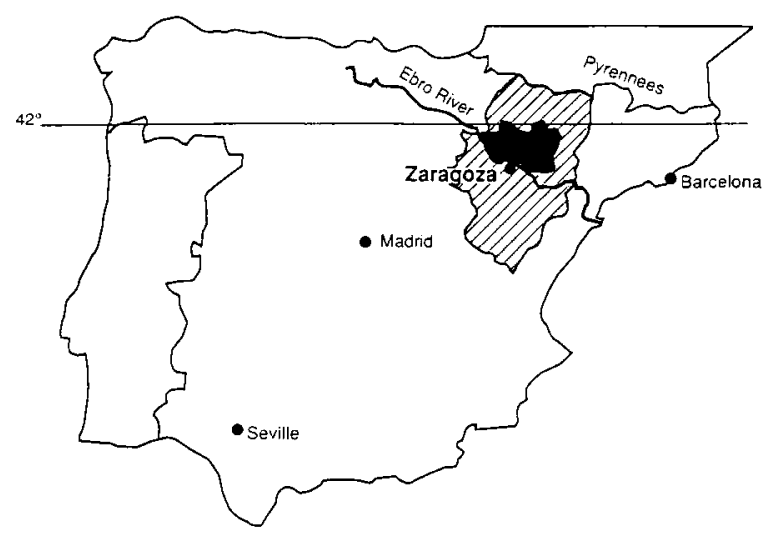

Fig 1. Map of the Iberian peninsula with hatched area showing the Aragon region and the zone in black representing the areas of La Ribera del Ebro - Zaragoza and Los Monegros. yrs. Likewise, in the Great Konya Basin in Turkey, water stored during the fallow year was calculated to contribute between 45 and $65 \%$ of the water transpired by succeeding wheat crops (Janssen, 1972). More commonly, results are variable (French, 1978a, 1978b) and for this reason, experience obtained in other regions with differing soil and rainfall characteristics must be tempered with some local verification before advice can be given to farmers. We shall see below that one important difference between Central Aragon and some other semi-arid regions is the absence of a well-defined rainy season.

Central to the question of water use efficiency is the balance between water transpired $(T)$ by the crop and soil evaporation $(E)$. The sum of these 2 water budget components is commonly referred to as evapotranspiration (ET). E confers no or minimal physiological advantage upon the crop and thus represents a loss from the system. With an annual row crop, some soil evaporation is unavoidable and quantifying this loss under average conditions in Los Monegros is one of the aims of this study. On the other hand, many studies reviewed by de Wit (1958) and Tanner and Sinclair (1983) have shown dry-matter production ( $Y$ ) to be proportional to $T$. Tanner and Sinclair derive the following expression for the crop yield transpiration ratio:

$$
Y_{T} / T_{T}=\left(1 / T_{T}\right) \int\left[k T / B\left(\overline{e^{*}-e}\right)\right] d t
$$

where $Y_{T}$ is total dry matter (DM) mass/area, $T_{T}$ is the total transpiration/area, $\left(e^{*}-e\right)$ is the mean daytime difference between the saturated and actual vapour pressure, ie the mean daytime vapour pressure deficit, $k$ is a crop specific efficiency parameter, and the integration extends over the period of active dry matter (DM) accumulation. $B$ is a parameter close to unity provided leaf temperature does not depart substantially from air temperature and leaf area index exceeds 3 . In practice, and despite some caveats discussed by Tanner and Sinclair, equation [1] is usually reduced to the Bierhuizen and Slatyer (1965) formulation:

$$
Y_{T} / T_{T} \approx k_{d} /\left(\overline{e^{\star}-e}\right)
$$

where $k_{d}$ and $\left(\overline{e^{\star}-e}\right)$ are mean quantities over the period of growth. Because of the correlated nature of the variables of the integrand in equation [1], $k_{d}$ will be smaller than $k$ (Tanner and Sinclair, 1983). Monteith (1986) also shows data from the Rothamsted Experimental Station sup- 
porting the above equation. After an elegant reappraisal of previous work, Tanner and Sinclair conclude that $k$ (or $k_{d}$ ) is a stable characteristic of a cropping system. The mean daytime vapour pressure in the denominator of equation [2] serves as an index of aridity explaining differences in transpiration efficiency attained in varying climates.

The derivation of equations [1] and [2] both depend on the ratio of the leaf intercellular $\mathrm{CO}_{2}$ concentration $\left(c_{i}\right)$ to the atmospheric concentration $\left(c_{a}\right)$ remaining roughly constant over the usual conditions of crop growth. After the work of Wong et al (1979), $c_{/} / c_{a}$ is often taken as 0.7 for $\mathrm{C}_{3}$ and 0.3 for $\mathrm{C}_{4}$ species. While this assumption has since been questioned on theoretical grounds (Farquhar and Richards, 1984), the evidence cited by Tanner and Sinclair and that of Wilson and Jamieson (1985) (reproduced here in fig 2) suggest that equation [2] provides a description that is consistent with crop behaviour in the field. Wilson and Jamieson (1985) found a value for the above-ground DM production of wheat to be of $3.1( \pm 0.05) \mathrm{Pa}$ independent of cultivar, sowing date and season. In view of this, we will accept equation (2] as providing a useful framework within which to consider crop production and water usage in Central Aragon.

Since $\left(\overline{e^{\star}-e}\right)$ is largely defined by local climate, Tanner and Sinclair (1983) also conclude that the 'transpiration efficiency of total biomass is a relatively unmanipulative variable'. Thus the

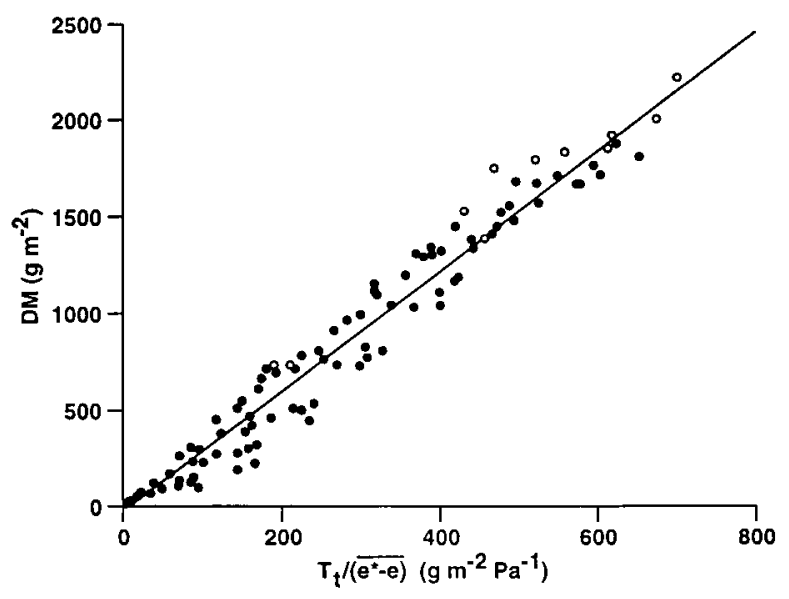

Fig 2. Relation between cumulative DM production from successive harvests and transpiration per unit vapour pressure deficit. Maximum harvests for the 11 crops ( 3 seasons, 2 cultivars, 2 or 3 planting dates) are represented by the open symbols. Total evapotranspiration was either measured directly using a neutron probe or calculated from a calibrated water budget. Soil evaporation was deduced using the procedure of Ritchie (1972) and Tanner and Jury (1976) (Reproduced by permission of Wilson and Jamieson (1985)). options available for more efficient use of limited water resources by rain-fed agriculture are reduced to:

- matching the phenology of the crop to the expected water supply, and/or to periods of low varpour pressure deficit;

- management techniques, which increase the proportion of water transpired by the crop relative to that wasted by weeds or soil evaporation; - increasing the total amount of water available.

Examples of these 3 strategies respectively include, choice of crop, cultivar and sowing dates to maximize growth when vapour pressure deficits are low, fertilization to encourage more rapid canopy development and thus in turn increase transpiration relative to soil evaporation, and lastly, fallowing and/or terracing. Breeding opportunities would seem to lie mostly in improving the harvestable proportion (harvest index) of the crop (Tanner and Sinclair, 1983) or developing shorter season varieties (Cooper et al, 1987).

This paper examines some aspects of the water budget in relation to crop performance within a traditional wheat-fallow rotation in the Los Monegros region. Rainfall statistics and grain yields are used to determine the importance of withinseason and fallow period rainfall contributions to grain yields. As discussed by Tanner and Sinclair (1983), equation [2] gives an upper limit for water use efficiency and predictions based on this calculation will be compared those achieved in practice. This equation also provides the basis of a methodology, which, in low rainfall environments, allows $E T$ to be easily decomposed into $E$ and $T$ components.

\section{ENVIRONMENT}

\section{Climate}

Monthly rainfall statistics are listed in table I together with evaporation estimates. Monthly rainfall totals (1941 to 1989) were available from Monegrillo within a few kilometers of the site from whence yield data were obtained. The maximum daily rainfall within each month was also available. Average Priestley and Taylor (1972) monthly evaporation figures $\left(E T_{0}\right)$ were calculated from hours of sunshine data tabulated by Faci and Martínez (1991). Only in December and January does the average rainfall exceed 
Table I. Evapotranspiration and rainfall statistics.

\begin{tabular}{|c|c|c|c|c|c|c|}
\hline Month & $E T_{0}{ }^{a}$ & $\begin{array}{c}\mathrm{R} \\
(m m)\end{array}$ & $\sigma^{\mathrm{b}}$ & $\mathrm{P}(\mathrm{R}<10)^{c}$ & $\begin{array}{l}\mathrm{P}(\mathrm{R}>50) \\
(\%)\end{array}$ & $\mathrm{P}(\mathrm{RD}>30)^{d}$ \\
\hline
\end{tabular}

\begin{tabular}{|c|c|c|c|c|c|c|}
\hline Jan & 17 & 24 & 22 & 33 & 12 & 4 \\
\hline Feb & 37 & 25 & 23 & 29 & 12 & 6 \\
\hline March & 82 & 26 & 25 & 29 & 12 & 2 \\
\hline April & 115 & 39 & 38 & 22 & 27 & 10 \\
\hline May & 149 & 51 & 30 & 8 & 43 & 32 \\
\hline June & 168 & 35 & 27 & 20 & 18 & 22 \\
\hline July & 168 & 22 & 25 & 47 & 12 & 12 \\
\hline August & 148 & 24 & 20 & 35 & 18 & 20 \\
\hline Sept & 118 & 34 & 37 & 31 & 31 & 22 \\
\hline Oct & 60 & 37 & 37 & 31 & 18 & 18 \\
\hline Nov & 43 & 32 & 35 & 18 & 16 & 14 \\
\hline Dec & 18 & 29 & 26 & 25 & 21 & 8 \\
\hline Annual & 1122 & 377 & 95 & & & \\
\hline
\end{tabular}

a $E T_{0}=1.26(s / s+\gamma) R_{n}$ where $s$ is the slope of the saturated vapour pressure curve at the daily mean temperature, $\gamma$ is the psychrometric constant, and $R_{n}$ the $24-\mathrm{h}$ net radiation ; ${ }^{b} \mathrm{SD}$ of monthly rainfall ; ${ }^{c}$ probability of montly rainfall total $<10 \mathrm{~mm} ;{ }^{d}$ probability of a single day's rainfall $>30 \mathrm{~mm}$.

the estimated atmospheric demand. Some indication of the chronic deficiency of water in this region is given by the disparity between the average annual rainfall $(377 \mathrm{~mm})$ and estimated "potential' evaporation (1 $122 \mathrm{~mm}$ ).

Effects of drought can be accentuated by dry WNW winds (Cierzo) during March and April. Less frequently there are dry winds from the south at the end of May or beginning of June during grain filling. Mean daily temperatures (table II) range from $5^{\circ} \mathrm{C}$ in January to $26^{\circ} \mathrm{C}$ in July and with extreme temperatures sometimes exceeding $40^{\circ} \mathrm{C}$ and as low as $-10^{\circ} \mathrm{C}$ (Biel and García de Pedraza, 1962).

Average monthly values of $\left(\overline{e^{*}-e}\right)$ listed in table II show the expected seasonal increase in dryness. An average of $556 \mathrm{~Pa}$ was calculated over the period of maximum DM accumulation (January through May). Since local measurements of wet bulb temperature or humidity were not available, these values were estimated from the corresponding long-term average monthly minimum and maximum air temperatures ( $T_{\text {min }}$ and $T_{\max }$ respectively). Vapour pressure deficits were weighted towards the period of higher daytime temperatures and solar radiation loading assuming:

$$
\left.\overline{\left(e^{*}-e\right.}\right)=2 / 3\left(e^{\star}\left(T_{\max }\right)-\mathrm{e}^{\star}\left(T_{\min }\right)\right)
$$

after Tanner and Sinclair (1983). This assumes that air temperature approaches the dew point at night, ie that the actual vapour pressure is estimated as:

$$
e=e^{*}\left(T_{\min }\right)
$$

This procedure can at best only describe the long-term average behaviour of daytime vapour

Table II. Mean monthly minimum and maximum temperatures and estimated vapour pressure deficits.

\begin{tabular}{lcll}
\hline Month & $\mathrm{T}_{\min }\left({ }^{\circ} \mathrm{C}\right)$ & $\mathrm{T}_{\max }\left({ }^{\circ} \mathrm{C}\right)$ & $\begin{array}{c}\left(\mathrm{e}^{\star}-\mathrm{e}\right) \\
(\mathrm{Pa})\end{array}$ \\
\hline Jan & & & \\
Feb & 3.5 & 9.5 & 272 \\
March & 0.5 & 12.5 & 381 \\
April & 6.7 & 16 & 628 \\
May & 9 & 19 & 692 \\
June & 11.5 & 21.5 & 805 \\
July & 15.8 & 26.5 & \\
August & 17.5 & 29.5 & \\
Sept & 17.5 & 29 & \\
Oct & 15.5 & 25 & \\
Nov & 11 & 19 & \\
Dec & 49 & 14 & \\
Annual & 4 & 9 & \\
& 11.5 & 21 & \\
\hline
\end{tabular}


pressure deficit, and it is for this purpose only that we exploit these calculated values in the latter discussion. Almost identical values were calculated using monthly mean air temperatures and relative humidity data for Zaragoza (Biel and García de Pedraza, 1962).

\section{Soils}

No detailed soil information is available from the site where yields were collected, although studies of other soils in this area typically indicate a rooting depth of $50 \mathrm{~cm}$ and an 'available' waterholding capacity (between soil water potentials of -30 and $-1500 \mathrm{kPa}$ ) of $\approx 90$ to $100 \mathrm{~mm}$ (Alberto et al, 1979; Torres, 1983). Roughly half of this water can be considered readily available in the sense that soil water deficits less than this magnitude would not be expected to limit plant growth. Soils in this region are mostly alkaline (average $\mathrm{pH}$ in water 7.7-8.5) with low organic matter contents $(<1.5 \%)$. Total carbonate content can exceed 35\% (Montañés et al, 1991). Rooting depths of terrace soils may be limited by the presence of limestone layers (Alberto et al, 1982) and on sloping sites by the variable depth of deposited material from upslope erosion. In the latter situation, soil loss is a serious problem (Arrúe and López, 1991) and terracing is common for both soil and water conservation.

\section{CULTURAL PRACTICES}

Records of grain yields were obtained from a commercial farm $\approx 40$ to $50 \mathrm{~km}$ west of Zaragoza $\left(41^{\circ} 39^{\prime} \mathrm{N}, 1^{\circ} 00^{\prime} \mathrm{W}\right)$ in the Los Monegros area (fig 1). This same data set was also used by Alberto and Machin (1978) to demonstrate the strong correspondence between annual rainfall and grain yields.

As is traditional in this area, wheat was cultivated using a crop-fallow rotation (año $y$ vez). Farming operations usually being in January or February with deep tillage using a moldboard plough. In May or June a second lighter tillage operation is carried out. The fields are then not ploughed again until the end of September or early October when seedbed preparation is carried out prior to sowing (de los Ríos, 1982). Sowing generally takes place in October or early November. Tillering occurs in early January, anthesis in mid-to-late April and harvest between the 10th and 30th of June. Nitrogen applications have not been common practice.

\section{RESULTS AND DISCUSSION}

\section{Rainfall}

Spectral analysis of the 1941-1989 time-series of monthly rainfalls revealed no patterns or significant harmonics. On the other hand, conventional statistics of the monthly values (table I) revealed several important features of the rainfall pattern. Firstly, and in contrast to many other semi-arid regions, we note the uniformity of average monthly totals and the absence of any well-defined rainy season. A second feature is the high between-year variability as characterised by SDs which are comparable in magnitude to the average monthly totals. Figure 3 shows a histogram of the average monthly rainfall distribution. Only May departs significantly from this general exponentially-decreasing pattern of rainfall totals by having a more symmetrical distribution, peaking at 40-50 $\mathrm{mm}$.

In each month there is a significant probability of having either an extremely low amount $(<10 \mathrm{~mm}$ ) or no rain at all (table l). Evaporation of soil or foliage wetted by infrequent small showers occurs rapidly and has little effect on soil or plant water status. It is only the occasional large events that contribute significantly to soil water storage. The final 2 columns in table I attempt to emphasise such rainfall events monthly totals $>50 \mathrm{~mm}$ and the probability of rainy days within each month with a rainfall $\geq 30 \mathrm{~mm}$. This is an arbitrary threshold which is approximately equal to the average monthly rainfall. There is a significantly higher probability

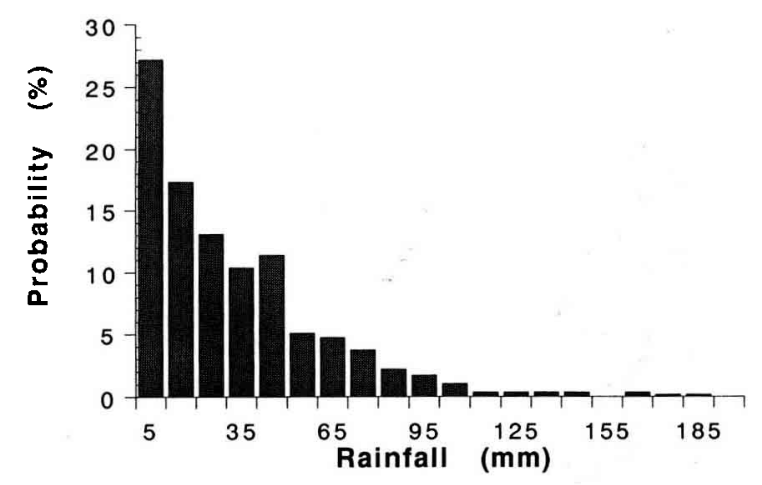

Fig 3. Histogram showing the averaged probability of monthly rainfall totals falling within $10-\mathrm{mm}$ intervals. 
of such events in May and in September. The former benefits the post-anthesis grain-filling period whilst the latter which occurs just prior to sowing may also be useful, although the potential for evaporation is high in this period.

\section{Potental evapotranspiration}

It will be seen that most of the fluctuations in yields can be ascribed to differences in rainfall; and on an annual or seasonal time scale, this variable also limits evapotranspiration. Under the dryland conditions of interest in the current study, potential evaporation has only a notional value as there is little prospect of high evaporative demands being satisfied for long periods. Nevertheless, some brief comment is required on our use of the Priestley and Taylor (1972) method to estimate the likely water use under well-watered conditions. In temperate regions, this simple empirical method has enjoyed considerable success. In New Zealand, for example, McNaughton et al (1979) found daily and weekly estimates to agree with Bowen ratio-energy budget measurements to within $\pm 15 \%$ and $\pm 5 \%$ respectively. Scotter et al (1979) and McAneney and Judd (1983) also found agreement between measured and estimated water extraction from pastures.

The Priestley and Taylor method does not account for advection, and finding an operational way of dealing with this effect remains an unresolved problem for local advection theory. Lysimeter measurements from locally well-watered grass in the Rhone Valley clearly show the magnitude of possible advective effects with evaporation rates on occasions exceeding twice the Priestley and Taylor predictions due to Mistral winds and regional drying (Seguin, 1977). In Aragon, Cierzo wind events may well play a similar role to that of the Mistral. However, within a large area (250 ha) of irrigated land on the Crau Plain (northwest of Marseille), the accumulated daily evaporation measured over $100 \mathrm{~d}$ was almost exactly that predicted by the Priestley and Taylor method (Seguin et al, 1982). The Crau is also subject to the Mistral. Thus the performance of the Priestley and Taylor method does seem to provide an acceptable average prediction of water consumption from well-watered crops even in a semi-arid region as time and space scales increase.

\section{Water balance}

The nature of the rainfall $(R)$ distribution in this region (see earlier discussion), means that drainage and, on flat sites, runoff can usually be neglected. Thus at a good first approximation, the soil water budget simplifies to:

$$
R \approx E T+\Delta S=T+E+\Delta S
$$

where $\Delta S$ is the change in root zone soil water storage over the time period in question. In a later discussion, regression analysis will be employed to examine relationships between yields and seasonal or annual rainfall totals with the assumption that $R$ and $E T$ are equal, ie that on these time scales $\Delta S$ is negligible. The corollary to this is that:

$$
T_{T}=E T_{T}-E_{T} \approx R_{T}-E_{T}
$$

where subscripts denote seasonal totals. Substituting for $T_{T}$ from equation [2], we obtain:

or

$$
E_{T} \approx R_{T}-Y_{T}\left(\overline{e^{\star}-e}\right) / k_{d}
$$

$$
R_{T} \approx R_{T}-\left(Y_{G} / \beta\right)\left(\overline{e^{*}-e}\right) / k_{d}
$$

where $\gamma_{G}$ is the grain yield and $\beta$ the harvest index. In principle, this approach allows the seasonal $E$ to be estimated from DM and rainfall totals to the extent that seasonal drainage and runoff losses can be safely assumed to be minor.

A simple geometrical interpretation of equation [3] is possible. Grain yields are first plotted as the dependent variable against seasonal rainfall as in figure 5 . A line of slope $\left(\overline{e^{\star}-e}\right) / \beta k_{d}$ from any point will intercept the rainfall axis to give the seasonal soil evaporation $E_{T} . T_{T}$ is obtained from the projection of the line on the rainfall axis (ie= $R_{T}-E_{T}$ ). Routine use of equation [3] demands measurements of the daily vapour pressure deficit. In absence of such data, we must content ourselves in the present case with estimating long-term average values of $E_{T}$ and $T_{T}$.

\section{Relationships between yields and rainfall}

Prior to attempting to evaluate individual components of the water budget, we first examine the dependence of yields on rainfall and the effec- 
tiveness of the fallow period in terms of its contribution to subsequent plant growth. The remarkable variability in annual grain yields and their close relationship with fluctuations in the seasonal (October to May inclusive) rainfall is illustrated in figure 4. The reasons for our use of the seasonal rainfall $\left(R_{T}\right)$ and the neglect of rainfall accumulated during the fallow period will emerge in later discussion. Yields are low compared with the $7500 \mathrm{~kg} / \mathrm{ha}$ possible under irrigation and with heavy nitrogen treatments (Experimental Farm Records, Estación Experimental de Aula Dei). There are no years when yields are high and seasonal rainfall low. Similarly low seasonal rainfalls always correspond to low yields. This high correspondence between the 2 time-series suggests that at this site, either because of rainfall or soil characteristics, storage of rainfall accumulated over the 18-month fallow period is relatively unimportant compared with within-season precipitation. This could be due either to a low soil water holding capacity at this site and/or poor control of weeds. If this were not the case, then recharge during the fallow period would act to buffer or smooth yields, and reduce their evident dependence on $R_{T}$. Figure 5 illustrates more directly the relationship between grain yield $\left(Y_{G}\right)$ and $R_{T}$ and results in the following regression statistics:

$$
Y_{G}=6.94( \pm 0.86) R_{T}-670( \pm 228)
$$

The relation has a coefficient of determination $\left(r^{2}\right)$ of 0.66 and a residual standard deviation about the line $(r s d)$ of $447 \mathrm{~kg} / \mathrm{ha}$. For $R_{T} \approx<100$ $\mathrm{mm}$, there is no harvestable yield. The physical interpretation of this rainfall threshold, which was not satisfied in 2 of the 35 years, will be discussed in the next section.

The importance of rainfall during different parts of the season was investigated via a series of linear regression analyses of grain yields versus the accumulated seasonal rainfall from the beginning of October. Changes in $r^{2}$ and $r s d$ as an increasing proportion of the season's total rainfall is included are shown in figure 6 . The best predictor of final yield appears to be the accumulated rainfall between October 1 and May 31 and it is this rainfall variable that is plotted in figure 4 . We call this the 'seasonal rainfall' $\left(R_{T}\right)$ as it encompasses the duration between seedbed preparation and maturation (see Cultural practices section). The inclusion of September's rainfall in the analyses actually decreased the rsd slightly, probably because the evaporative demand is still high at that time of the year compared with average monthly precipitation (table I). Similarly, the inclusion of the July rainfall during maturation did not improve the statistics.

If the local gradient or slope of the lines in figure 6 is interpreted as some measure of the sensitivity of final yields to rainfall in the corresponding period of the growth cycle, then the October through December period is clearly important. While the dependence of successful emergence on surface wetting by rainfall during this period is obvious, other influences must be acknowledged. The first is that in the absence of further significant rain in January and February, growth must occur using water stored in the soil profile during this early period whilst the soil is bare. This becomes more important if the fallow period was ineffective. On the other hand, in the case of a dry autumn, sowing and seedbed preparation may be delayed and several studies note the decrease in yields that occur with delayed sowing (French and Schultz, 1984; Cooper et al, 1987). Figure 6 also implies that rain in April is

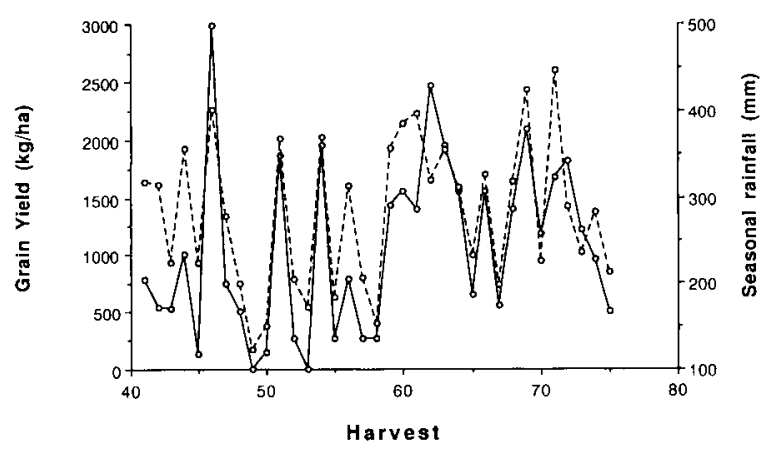

Fig 4. Time series of grain yields (solid line) and seasonal rainfall (dashed line).

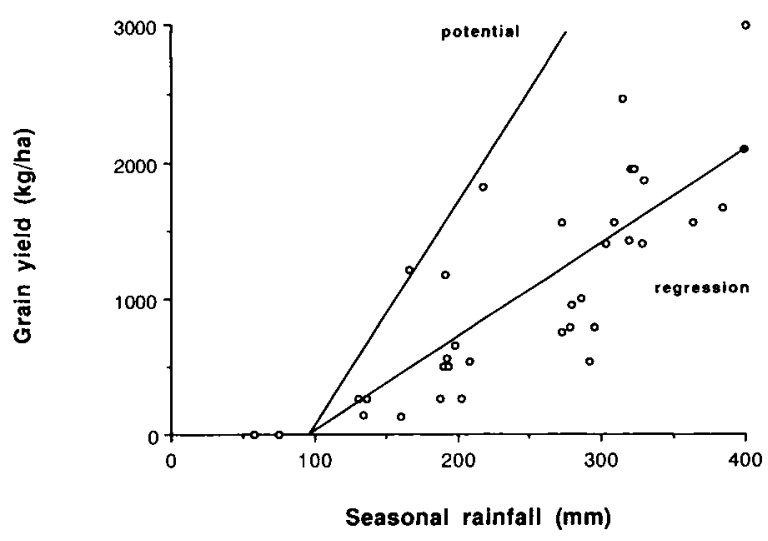

Fig 5. Grain yields versus seasonal rainfall. The slope of the upper line gives the average transpiration efficiency in this climate. The lower line is the regression relation (equation [4]). 


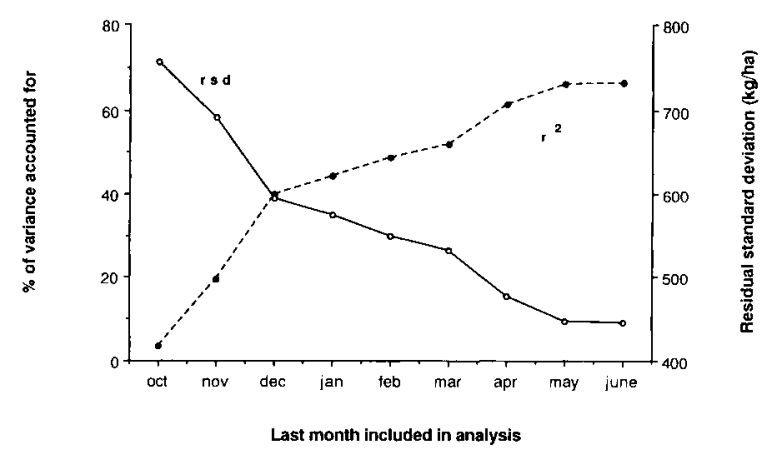

Fig 6. Change in regression statistics as grain yields were regressed against the accumulated rainfall since the beginning of October. The abscissa denotes the last month's rainfall included in the analysis.

important in the latter stages of leaf area development and DM accumulation. This is in accordance with the observation of local farmers that good rains in April lead to a good harvest (Faci, personal communication). We note that successive monthly rainfall totals are very poorly correlated with each other.

The same technique of successive regression was employed to elucidate the relation between grain yields $\left(Y_{G}\right)$ and rainfall accumulated for different proportions of the preceding fallow period. The improvement was slight with the best results being obtained between grain yields and the 12month period between June to May inclusive (R12):

$$
\begin{aligned}
Y_{G} & =5.81( \pm 0.70) R_{12}-1067( \pm 269) \\
& \approx 5.8\left(R_{12}-184\right)
\end{aligned}
$$

with an $r^{2}$ of 0.69 and $r s d=492 \mathrm{~kg} / \mathrm{ha}$. Note that $R_{12}$ includes $R_{T}$. Going further back into the fallow period, the 2 variables become less and less related until there is little correlation between yields and the total 24 month rainfall $\left(r^{2}=0.37\right.$, $r s d=622)$. This result is not unexpected, given the strong direct linkage between $Y_{G}$ and $R_{T}$ manifest in figure 4.

\section{Water-use efficiency}

It is instructive to rewrite [4] as:

$$
Y_{G} \approx 7\left(R_{T}-100\right)
$$

It is usual (Hanks et al, 1969; French and Schultz, 1984) to interpret the intercept (100 $\mathrm{mm}$ ) on the abscissa as soil evaporation. In a slight departure from common practice, we assign this $100 \mathrm{~mm}$ as the minimum evaporative loss. This is the unavoidable loss given an annual row crop which has a significant proportion of bare soil during the early part of the season. Depending on the season and leaf area development, evaporative losses may be greater (but never less) than this figure, which comprises $40 \%$ of the average seasonal rainfall $(255 \mathrm{~mm})$. While there is considerable scope for variation in this value depending on site, seasonal and rainfall characteristics, it clearly represents a significant proportion of what is, in Mediterranean regions at least, a very limited resource. On an annual basis, the intercept of equation [5] amounts to $184 \mathrm{~mm}$ or $\approx 50 \%$ of the annual rainfall.

We now attempt to estimate the average total evaporative loss from this soil along the lines suggested by equation [3]. An average seasonal $\left(\overline{\left.e^{*}-e\right)}\right.$ of $556 \mathrm{~Pa}$ was estimated (see Climate section) for the January through May period of maximum dry matter accumulation. Substituting this value into equation [2] and using a $k_{d}$ of 3.1 $\mathrm{Pa}$ (Wilson and Jamieson, 1985), we obtain a potential yield of $56 \mathrm{~kg}^{\circ} \mathrm{ha}^{-1}$ per $\mathrm{mm}$ transpiration for $\mathrm{DM}$ production. If the average harvest index is assumed to be 0.3 (average value obtained in a similar climate in South Australia by French and Schultz (1984)), then the potential transpiration efficiency for grain yield is $16.7 \mathrm{~kg}^{\circ} \mathrm{ha}^{-1} \bullet \mathrm{mm}^{-1}$. That this figure is in satisfactory agreement with the slope of the 'potential' line (15 $\left.\mathrm{kg}^{\circ} \mathrm{ha}^{-1} \bullet \mathrm{mm}^{-1}\right)$ shown in figure 5 gives some confidence in the use of equation [2]. This maximal line represents the boundary which the data does not exceed and also represents an upper limit to water-use efficiency in this climate. French and Schultz (1984) also used this approach to estimate potential transpiration efficiency under South Australian conditions. Variation in published values (15.8 to $23.4 \mathrm{~kg}^{\circ} \mathrm{ha}^{-1} \cdot \mathrm{mm}^{-1}$ for grain production) is attributable to differences in both mean seasonal vapour pressure deficits and harvest indices.

The water use efficiency of grain production after discounting the $100 \mathrm{~mm}$ minimum soil evaporation approached the calculated average yield: transpiration ratio in only 3 out of 35 years. In other years, $E$ presumably accounted for a greater proportion of $E T$, reflecting reductions in growth due to factors other than water such as extremes of temperature, effects of pests and diseases, and nutritional deficiencies which may 
restrict leaf area development. We recall that the DM: transpiration ratio is constant (Tanner and Sinclair, 1983 ; Wilson and Jamieson, 1985) and this will also be true for grain production if the harvest index does not vary greatly. While typical values of the harvest index have been adopted for this study of historical yields, measurement of this quantity is recommended in future investigations.

We now estimate the average transpiration from the ratio of the yield: transpiration ratio (slope of the potential line in fig 5), and the regression equation representing the average condition (equation [6]):

$Y_{G} / T_{T}=15$ and $Y_{G} /\left(R_{T}-100\right) \approx 7$

to obtain:

$$
T_{T} \approx 0.47\left(R_{T}-100\right)
$$

and therefore:

$$
E_{T} \approx R_{T}-T_{T} \approx 0.53 R_{T}+47
$$

After substituting for an average $R_{T}$ of $255 \mathrm{~mm}$, we find that on average $E$ accounts for some $70 \%$ of the seasonal rainfall. Note that these evaporative losses also include evaporation of intercepted rainfall directly from foliage surfaces. Cooper et al (1987) cite studies in Syria, where measured losses from evaporation ranged from 35 to $55 \%$ of $E_{T}$ attaining $75 \%$ in the case of an unfertilised barley crop. We speculate that under traditional cultural practices, where fertiliser applications were not common, low fertility would often limit yields in the Los Monegros and La Ribera del Ebro-Zaragoza areas, particularly in years with higher rainfall.

\section{CONCLUSIONS}

Under the climatic conditions of Central Aragon, wheat yields are closely related to seasonal rainfall. The evidence for justifying a fallow period on the basis of its contribution of stored water to subsequent yields is not strong. This may be due to soil characteristics, shallow rooting and/or ineffective weed control. The uncertain nature of the rainfall distribution and the absence of any welldefined rainy season must also be important contributing factors.

The proposal that the constancy of the transpiration efficiency (Tanner and Sinclair, 1983) be exploited to calculate transpiration from yields departs from conventional practice. Traditionally, equation (2) or its predecessors (eg de Wit, 1958) have been used to calculate DM production from water balance measurements. In reversing this procedure, we take advantage of the relative ease of measuring yields and the subsequent estimation of transpiration follows directly. In many semi-arid regions, evaporation can then be calculated by difference from the seasonal rainfall provided drainage or runoff losses can be neglected. Routine use of this methodology would require measurements of vapour pressure deficit and harvest indices (or total DM). Because of the importance of the former, we should take cognisance of the comment by Butler (1992) regarding the need to measure humidity rather than make assumptions about it. Similar sentiments have also been expressed by Monteith (1986).

In applying the above methodology to central Aragon, we calculate an average potential grain yield: transpiration ratio of $16.7 \mathrm{~kg}^{\bullet} \mathrm{h}^{-1} \cdot \mathrm{mm}$ water transpired. This potential was approached in only 3 or 35 years. A high proportion of the seasonal rainfall $(70 \%$ on average) is estimated as being lost either by evaporation or by weed transpiration. This result is consistent with the low average yields. We speculate that leaf area development is often limited by low fertility. These conclusions will serve as working hypotheses for experimental investigations of crop water relations currently in progress.

\section{ACKNOWLEDGMENTS}

This work was made possible with financial help from the Programma Europa de Estancias de Investigación (CAI-CONAI/DGA), Zaragoza, Spain, and the New Zealand Ministry of Agriculture and Fisheries.

\section{REFERENCES}

Alberto F, Machín J (1978) Delimitación de áreas de suelos con régimen de humedad árido en la depresión media del Ebro. Trab Compostelanos Biol 6, 29-45

Alberto F, Machín J, Cuchi JA, Poza MR (1979) Memoria y Guia de la Excursiones Científicas. VIII Reunión Nacional de Suelos, Est Exp Aula Dei, Zaragoza, $109 \mathrm{pp}$

Alberto F, Arrúe JL, Machín, Cambra M, Herrero J (1982) Los suelos pardos de costra caliza de la de- 
presión media del Ebro. Relaciones entre la profundidad del suelo y el crecimiento y producción de frutales. Anal Aula Dei 126, 111-130

Arrúe JL, López MV (1991) Laboreo de conservación: tendencias y prioridades de investigación. Suelo Planta 1, 555-564

Biel A, García de Pedraza L (1962) El Clima de Zaragoza y Ensayo Climatológico para el Valle del Ebro. SMN Publ Ser A (memorias) No 36

Bierhuizen JF, Slatyer RO (1965) Effect of atmospheric concentration of water vapour and $\mathrm{CO}_{2}$ in determing transpiration - photosynthesis relationships of cotton leaves. Agric Meteorol 2, 259-270

Butler DR (1992) Daily patterns of dew-point temperature in a semi-arid climate. Agric For Meteorol 60, 267-278

Cooper PJM, Gregory PJ, Tully D, Harris HC (1987) Improving water use efficiency of annual crops in the rainfed farming systems of West Asia and North Africa. Exp Agric 23, 113-158

de los Ríos F (1982) Informe Sobre los Monegros. Fernando el Católico, Publicación N 850, Geographicalia, Ser Monográfica 2, pp 142

de Wit CT (1958) Transpiration and Crop Yields. Inst Biol Chem Res On Field Crops and Herbage, Wageningen, The Netherlands, Verse-Landbouk, Onder Z No 64.6-S, p 88

Hanks RJ, Gardner HR, Florian RL (1969) Plant growth-evapotranspiration relations for several crops in the central great plains. Agronomy $J 61$, 30-34

Faci JM, Martínez A (1991) Cálculo de la Evapotranspiración de Referencia en Aragón. Diputación General de Aragón, Zaragosa, $115 \mathrm{pp}$

Farquhar GD, Richards RA (1984) Isotopic composition of plant carbon correlates with water-use efficiency of wheat genotypes. Aust J Plant Physiol 9, 121-137

French RJ (1978a) The effect of fallowing on the yield of wheat. 11. The effect on soil water storage and nitrate supply. Aus J Agric Res 29, 653-667

French RJ (1978b) The effect of fallowing on the yield of wheat. 1. The effect on grain yield. Aust J Agric Res 29, 669-684

French RJ, Schultz JE (1984) Water use efficiency of wheat in a Mediterranean-type environment. 1. The relation between yield, water use and climate. Aust J Agric Res 35, 743-764

Janssen $\mathrm{BH}$ (1972) The significance of the fallow year in the dry-farming system of the Great Konya Basin, Turkey. Neth J Agric Sci 20, 247-260
McAneney KJ, Judd MJ (1983) Pasture production and water use measurements in the central Waikato. $N Z J$ Agric Res 26, 7-13

McNaughton KG, Clothier BE, Kerr JP (1979) Evaporation. In: Physical Hydrology-NZ Experience (Murray $\mathrm{PL}$, Ackroyd $\mathrm{P}$, eds) NZ Hydrol Soc, Wellingtonn, pp 97-119

Montañés L, Sanz M, Heras L (1991) Fertilidad de Los Suelos de Secano en la Provincia de Zaragoza. Diputación General de Aragón, Zaragoza, pp 233

Monteith JL (1986) How do crops manipulate water supply and demand? Phil Trans $R$ Soc Lond A316, 245-259

Priestley CHB, Taylor RJ (1972) On the assessment of surface heat flux and evaporation using large scale parameters. Mon Weather Rev 100, 81-92

Ritchie JT (1972) Model for predicting evaporation from a row crop with incomplete cover. Water Resour Res 8, 1024-1213

Scotter DR, Clothier BE, Turner MA (1979) The soil water balance in a fragiaqualf and its effect on pasture growth in central New Zealand. Aust J Soil Res $17,455-465$

Seguin B (1977) Estimation de I'ETP en climat Méditerranéen du sud-est de la France. Méteorologie $11,33-40$

Seguin B, Baelz S, Monget JM, Petit V (1982) Utilisation de la thermographie IR pour l'estimation de l'évaporation régionale. 1 . Mise au point méthodologique sur le site de la Crau. agronomie 2, 7-16

Smika DE (1970) Summer fallow for dryland winter wheat in the semi-arid great plains. Agron J62, 1517

Tanner CB, Jury WA (1976) Estimating evaporation and transpiration from a row crop during incomplete cover. Agron J 68, 239-243

Tanner CB, Sinclair TR (1983) Efficient water use in crop production: research or research? In: Limitations to Efficient Water Use in Crop Production (Taylor HM, Jordan WR, Sinclair TR, eds) ASDACSSA-SSSA, Madison, WI, 1-27

Torres MM (1983) Balance hidrosalino de un poligono de riego en los Llanos de la Violada (Huesca). Tesis de Master, IAMZ, Zaragoza, pp 274

Wilson DR, Jamieson PD (1985) Models of growth and water use of wheat in New Zealand. In: Wheat Growth and Modelling. Proc NATO Adv Res Workshop, Bristol, April 1984. Plenum Publ Corp, NY

Wong SC, Cowan IR, Farquhar GD (1979) Stomatal conductance correlates with photosynthetic capacity. Nature 282, 424-426 